\title{
Usage of Information Communication Technologies for Training Prospective Mathematics Teachers in the Context of Dual System of Education in Ukraine
}

\author{
Olha Matiash, Liubov Mykhailenko*, Alina Voievoda, Liudmyla Nakonechna, Ihor Kalashnikov, \\ Viacheslav Olshevskyi
}

Department of Algebra and Mathematics Teaching Methods, Vinnytsia Mykhailo Kotsiubynskyi State Pedagogical University, Ukraine

Received August 24, 2020; Revised October 23, 2020; Accepted November 1, 2020

\section{Cite This Paper in the following Citation Styles}

(a): [1] Olha Matiash, Liubov Mykhailenko Alina Voievoda, Liudmyla Nakonechna, Ihor Kalashnikov, Viacheslav Olshevskyi, "Usage of Information Communication Technologies for Training Prospective Mathematics Teachers in the Context of Dual System of Education in Ukraine," Universal Journal of Educational Research, Vol. 8, No. 12, pp. 6641-6650, 2020. DOI: 10.13189/ujer.2020.081228.

(b): Olha Matiash, Liubov Mykhailenko Alina Voievoda, Liudmyla Nakonechna, Ihor Kalashnikov, Viacheslav Olshevskyi (2020). Usage of Information Communication Technologies for Training Prospective Mathematics Teachers in the Context of Dual System of Education in Ukraine. Universal Journal of Educational Research, 8(12), 6641-6650. DOI: 10.13189/ujer.2020.081228.

Copyright $\bigcirc 2020$ by authors, all rights reserved. Authors agree that this article remains permanently open access under the terms of the Creative Commons Attribution License 4.0 International License

Abstract On the base of the analysis of the state of mathematical and pedagogical education, the importance of the dual form of education for the training of the prospective mathematics teachers in Ukraine is explained. The advantages of combining the university education with the work place training are highlighted. The experience of the education systems of the USA and the Netherlands, regarding the training of the prospective mathematics teachers at the work place at school, has been analyzed. It is substantiated that the relevance of the dual form of education for training of mathematics teachers will promote the development and testing of specialized learning and teaching support materials for the students in the condition of dual education. Electronic didactic project of the lesson in mathematics, developed and tested by the authors is presented as the electronic tool, intended for practical training, namely, as computer-based functional, its main function is to create the conditions for individual activity and information interaction between the teacher and the student in the process of formation skills of future teachers of mathematics, needed for preparation for the mathematics lesson. By the results of the survey of the experts, it has been determined that the training of the future mathematics teachers to prepare for the lessons of mathematics with the help of the suggested electronic didactic projects of the lessons enables to form the ability to prepare viable project of the lesson; creates the conditions for rapid and efficient methodical aid from the experienced teachers; teaches to take into consideration various components in the process of the lessons preparation; makes comprehend each structural component of the lesson. The conclusion is made, regarding the possibility and expediency of applying the suggested electronic didactic projects of the lessons to provide the efficient methodical training of the future teachers in the conditions of the dual education.

Keywords Prospective Mathematics Teacher, Dual Education, Information-Communication Technologies, Methodological Support, Training of Future Specialists, Electronic Didactic Project of the Mathematics Lesson

\section{Introduction}

\subsection{Problem Statement and Justification of Its Relevance}

The content of the notion "dual system" is often 
explained as the combination of the study in the education establishments with training at the place of work. One of the leaders in the sphere of training of the qualified personal is the European Union, this leading position is the result of the application of the dual system of the vocational training and study. Duality as the methodological characteristic of the vocational education provides the coordinated interaction of the education and production spheres for the training the qualified personal of a certain profile within the frame of the organizationally different forms of training. In Germany, in recent 15 years, the number of students doubled as a result of the growth of the dual education offer in higher education institutions [1].

During 2015-2017, the experiment of the organization of the education-production process with the elements of the dual form for the training of future specialists was carried out in four vocational education establishments in Ukraine. In 2017-2019, the implementation of the elements of the dual form of education took place in more than 150 vocational education establishments. Following the results of this experiment, the conclusion was made that the dual education was the efficient form of training for the applied specialties, connected with the sphere of production [2].

Is the problem of dual education for training future teachers of mathematics urgent? Nowadays, the results of the Ukrainian pupils in PISA - the most competent study of the secondary education are discussed, namely, that $36 \%$ of the Ukrainian pupils do not achieve the basic level of quantitative literacy. For the researchers, studying the state and prospects of the development of school mathematical education the situation is clear.

One of the reasons of such state is that the prospective students for the mathematical specialties of the pedagogical universities, i.e. future teachers of mathematics, have low starting level of the quantitative literacy. However, still greater problem is that the best graduates of mathematical specialties of the universities (having tried to earn money, being graduate students, not at school), refuse to work at school not least because of the low salary. Regional division of the pedagogical staff showed, that in all regions the share of teachers, aged 41-50 and 51 to 60 is prevailing. As a result, in recent years for the mathematical specialties of the pedagogical universities the situation, when Master Students during the study work as the teachers of mathematics in schools, because there are many vacancies, is typical. The quality of such training, when the activity of the school and university is not coordinated, is obvious.

In the authors` opinion, the answer to the question if the dual education is important for the training of the future mathematics teachers in these conditions is definite absolutely necessary. In September 2018. Cabinet of Ministers of Ukraine approved the Concept of training specialists by the dual form of education [3]. The Concept states that the dual form of education can choose the students who study full-time or other forms of study, express personal desire and are selected by the employers. Thus, working at school, the students, on the condition in signing the corresponding agreements, can switch to the dual form of education. The Concept stresses, that the educational establishment bears the responsibility for the quality of students training, is responsible for the establishment of the cooperation between the educational establishment and employers and further effective communication of the parties.

The ability to prepare and conduct the efficient and interesting lesson of mathematics at school is a distinctive feature of the formed methodological competence of modern teacher of mathematics. In the process of communication with the experienced teachers of mathematics of the secondary schools of Vinnytsia and Vinnytsia Region (15 teachers of mathematics), the researchers learned that the overwhelming majority of teachers:

- prepare for the lesson designs the so-called extended plan of the lesson;

- consider the preparation for the efficient and interesting lesson to be a difficult task, which takes much time;

- greater part of teachers is interested in the application of the methodically grounded projects of the lessons to "construct" on this base their own lessons;

- use the Internet-resources to familiarize with the pedagogical experience of other teachers;

- search at the sites of the teachers of mathematics the developments of certain lessons.

Thus, even the experienced teachers of mathematics feel the need to improve the skills of preparing and conducting the lessons. In the conditions of dual education, the candidate must perform the work of the teacher, in particular, prepare and conduct lessons. For him, the quality preparation for the lesson is still the more important and complicated problem than for the beginning teachers, who have completed their study at the Pedagogical Universities. In the conditions of the dual education, the University bears the responsibility for the quality of the students, it is responsible for the establishment of the communication between the University and school, as well as for the efficient communication with the students-teachers. It is evident that without the application of the information communication technologies, it is almost impossible to provide the efficient communication of the teacher-student with university teachers and, accordingly, ensure the quality of the dual education. That is why, the development and scientific substantiation of the methodological support of future mathematics teachers training in the conditions of the dual education, in particular, training resources, needed for the efficient formation of their competence to perform proper preparation for the lesson of mathematics at school, becomes urgent. 


\subsection{Analysis of the Latest Research and Publications}

The problem of the quality improvement of the prospective mathematics teachers training is considered to be relevant almost all over the world. The experience of the American teachers regarding the organization of the professional training of the students - future teachers, the priority element of which is practical training, is of interest. On the base of the analysis of the papers [4-13], it can be stated that practical direction of the training, its functional value, possibility of practical application for the achieving of the teaching goals is a priority in the axiological orientations of the educational system of the United States. The important component of the system of the pedagogical education of the USA, connected with practical training of the future teachers in the condition of school, became the schools of the professional development - innovation establishments created on the base of the partnerships between the teacher training colleges of the university and comprehensive secondary schools of different levels, from primary to higher school [5]. The tasks of the schools of the professional development are to provide fundamental professional training by means of the intensive professional experience. C. Jackson's paper (2018) "Prospective mathematics teacher preparation: exploring the use of service learning as a field experience" [4] contains the results of the experiment, carried out by the teachers of a large state University of the South-Eastern Region of the United States. The data collected by the authors from reflective essays and interviews showed the impact of the combining of future teachers training in educational establishments with the work place training. The results of the study prove the positive impact of school-university partnership, aimed at better training of the prospective mathematics teachers and adding arguments in favor of the introduction of the dual education, or at least, its elements.

Training of the mathematics teachers at the work place in school or the immersion in the school curriculum at the work place [14] is the major component of the training programs for the mathematics teachers training in the Netherlands. In Bachelor's degree program, it represents approximately $25 \%$ of the total program. In Master's degree program of the future mathematics teachers training, approximately $50 \%$ of the program takes place in the secondary school [15]. Work place training is organized not only by means of the conventional traineeship. Pedagogical institutions search for close cooperation and partnership with the secondary education establishments [16]. This cooperation is fruitful for both parties. From the point of view of future mathematics teachers training, the motivating education environment, where the future teachers can integrate theory and practice and where there is a possibility to become a member of the professional community is created [17]. From the point of view of school, there is a possibility of the professional growth for the working teachers, the possibility to work over the innovations and research through cooperation with the educational establishment, which trains future teachers [15]. Besides, the developers of the educational policy in the Netherlands think that the share of procedural knowledge in the study of mathematics is rather large. That is why, at the given moment the special emphasis is made on the balanced knowledge of mathematics, including the procedural, conceptual and metacognitive knowledge. The balanced knowledge comprises active usage of the software as a didactic tool and hardware facilities, such as graphing calculators and smart black-boards, innovative approaches, namely "blended learning", etc. $[5,18]$. Application of the computers in the sphere of education resulted in the advent of new generation of information education technologies, which enabled to improve the quality of education, create new means of influence, perform more efficient communication between teachers and students [19]. In the opinion of many specialists [4-9,19,24], new information technologies, based on the application of the computing facilities, give the possibility to improve, considerably the efficiency of teaching mathematics and the efficiency of future mathematics teachers training. However, the application of the information communication technologies in education process to realize the efficient training of future mathematics teachers in the conditions of the dual education still requires scientific justification.

Aim of the paper is to substantiate the possibility and the feasibility of using electronic teaching facilities (on the example of electronic didactic project of the lesson of mathematics) to promote high quality of the future mathematics teachers training in the conditions of the dual education.

\subsection{Theoretical Fundamentals of Research}

The Laws of Ukraine "On Education" [20] and "On Higher Education" [21] stipulate the right of every person to obtain education in various forms or a combining them, and define the main forms of obtaining education, dual education is among these forms. Dual form of higher education - it is the form of obtaining full time education, which envisages training at the work place at the enterprises, institutions, organizations for obtaining certain qualification in the volume from $25 \%$ to $60 \%$ of the total volume of the education program on the base of the contract (Article 48 in the version of the Law on Higher Education № 392-IX of 18.12.2019) [21].

According to the Concept of training specialists in the dual form of education [3], its aim is stage-by-stage elaboration of the fundamentals of the state policy aimed at improvement of the quality of the professional training of specialists on the base of the dual form of education. Nowadays (2019 and 2020) Ukraine is at the second stage of the realization of the Concept of dual education: development of the typical models of dual form of obtaining education in educational establishments, 
realization of the pilot projects of the dual form of obtaining education, assessment of the efficiency.

The Concept of dual education strictly distinguishes the tasks for education establishments, for the students and for the employers. The tasks of educational establishments are the following: provide theoretical training of the students, integrity of the education program, correspondence to the standards of education and professional standards, creation of the conditions for the students to obtain the competencies, which will provide the possibility to adapt to various conditions. The Concept of the dual education states that the educational establishment bears the responsibility for the quality of the students' education, it is responsible for the establishing the cooperation between the educational institution and employers and for further efficient communication of the parties. At the same time, the student must perform at a proper level the tasks, imposed during the study at the work place and individual tasks in accordance with the curriculum.

The authors believe that it is possible to realize the above - mentioned tasks in the system of dual education of future mathematics teachers only at the condition of the qualitative methodical support, the key role in it will be performed by the information-communication technologies.

The confirmation of such point of view can be the thoughts of the teachers-researchers, working in the sphere of the dual education, who were involved in the all-Ukrainian experiment (2015-2017), dealing with the organization of the educational-production process with the elements of the dual form of education [2]. The teachers indicated the efficient methods of work, proved in the course of the experiment: methods of projects; gaming, computing, interactive, module technologies; trainings; case-technologies; simulation.

The researchers maintain the opinion of I.V. Stavytska [19] that "ICT perform active impact on the education process of the students, as they change the scheme of knowledge transfer and teaching methods. Certain problems in the usage of ICT arise as a result of the lack of not only the methodological base of their usage, but also the methodology of ICT development for the education, and make the teachers in practice orient only on the own experience and ability to search the ways of the efficient application of the information technologies empirically. At the same time, introduction of ICT in the education system not only influences the education technologies but also introduces new technologies in the education process".

It can be stated that the application of the computers in the process of education leads to the emergence of new educational technologies, which enables to provide the quality of future professionals training, create new means of impact, more efficient communication with students. To perform qualitative training of future teachers in the conditions of the dual education, it is important to understand the particular role and place of information communication teaching technologies and have the corresponding qualitative complex of the methodological support. Consequently, it seems appropriate that such complex, in the conditions of the dual education of the future mathematics teachers should contain the bank of electronic didactic projects of the lessons of mathematics.

The letter of the Ministry of Education and Science of Ukraine №1 / 9-630 of 05.12.2014 "On steadfast adherence to the principles of guaranteeing the freedom of teacher's pedagogical activity" [22] it is stated that: lesson planning is performed by the teacher in the arbitrary form, including the usage of the printed or electronic sources, etc. Format, volume, structure, content and execution of the lesson plans are the private business of the teacher. Establishment of the universal standards within the limits of educational establishment, town, district or region of such documents is inadmissible. Terms of their storage by the teacher are not determined by the legislation, that is why, the teacher makes the decision, regarding the term of storage individually. In many European countries and post-Soviet states, the teachers instead of writing the lesson plans create the didactic project of the lesson, where they plan the forms of the activity both of the pupils and teacher. Hence, the development and application of the electronic didactic project of the lesson of mathematics will promote the establishment of the communication between the teacher of the methodic of the mathematics teaching of the education establishment and the student of the dual form of education to provide rapid, methodologically substantiated consultation on one of the most important types of the methodical activity of the teacher - preparation to the lesson in mathematics.

\section{Materials and Methods}

The aim of the creation and usage of the electronic didactic project of the lesson of mathematics - is the training of the prospective mathematics teachers to prepare for the lessons of mathematics in the conditions of the profound analysis and individual consulting of the experienced teachers-supervisors. In the course of pilot work, the investigators obtained the model of the electronic didactic project of the lesson of mathematics (Fig. 1).

The framework of the lesson is developed on the base of the work books in the online model, using the server https://wizer.me/.

Theoretical block contains different theoretical information on the subject, the set of various definitions of new mathematical concepts of the theme, and so on.

Practical block contains a number of tasks for the actualization of the knowledge, tasks for summarizing the concept; tasks for searching the consequences from the notion; tasks for the consolidation of the knowledge, obtained in the standard situations; challenging tasks. 
Target block contains long list of the didactic, educational, developing aims of the lesson.

Motivation block contains the set of data for the motivation of the education activity of pupils at the lesson, in particular, historical references, problem situations, interesting applications.

Organization block contains the selections of the interactive constructors, scenarios of the didactic games, schemes of the organization of the individual learning activation of the study.

Diagnostic-correction block contains the assignments for the individual work of the pupils at the lessons, tasks for the case assessment of knowledge and skills on the subject, test assignments, assessment survey, mathematical dictations, etc.

The applied block contains the instructions for laboratory and practical work; assignments of the applied content, indicative topics for the project realization.

Methodical block contains methodical recommendations for the preparation of the lesson on the given subject, methodical recommendations for the solution of separate problems, video fragments of the lessons, conducted by the teachers of mathematics; references to the videos, located on the platform EdEra, Khan Academy.

Technological block contains the list of the program products which can be used at the lesson, for instance, Excel tables, GeoGebra, PowerPoint, etc., separate multimedia presentations.

In the process of the research - experimental work with the elaborated bank of the electronic didactic projects of the lessons of mathematics, the attention was concentrated on the organization of the methodical training of the students who, in parallel with the training, started pedagogical activity at school, teaching pupils the mathematics. These student-teachers allocated one of their most important problems - preparing of the qualitative lesson of mathematics takes too much time. The analysis of their lesson plans made the researchers realize that it is necessary to establish individual consultations of the teachers who begin their career, regarding various aspects of the organization of the efficient activity of the pupils at the lessons of mathematics. The following problems are really important: selection of the exercises, the sequence of their solution, technique of working with each problem, certain methods of generating pupils' interest in education material or to the process of the separate task solution, etc. These students have already understood that the borrowed lesson plan cannot take into account psychological and cognitive peculiarities of the pupils of certain class and methodological abilities and pedagogical principles of the teacher who conducts the lesson. Greater part of the interviewed students-teachers is interested in certain materials for the efficient preparation for the lessons of mathematics and they were convinced that such preparations should be in the electronic form. Students who, in parallel with the study at the University, started their pedagogical activity at school as the teacher of mathematics, in the given experimental work were experts in the field of application of the electronic didactic projects of the lessons of mathematics in the conditions of the dual education.

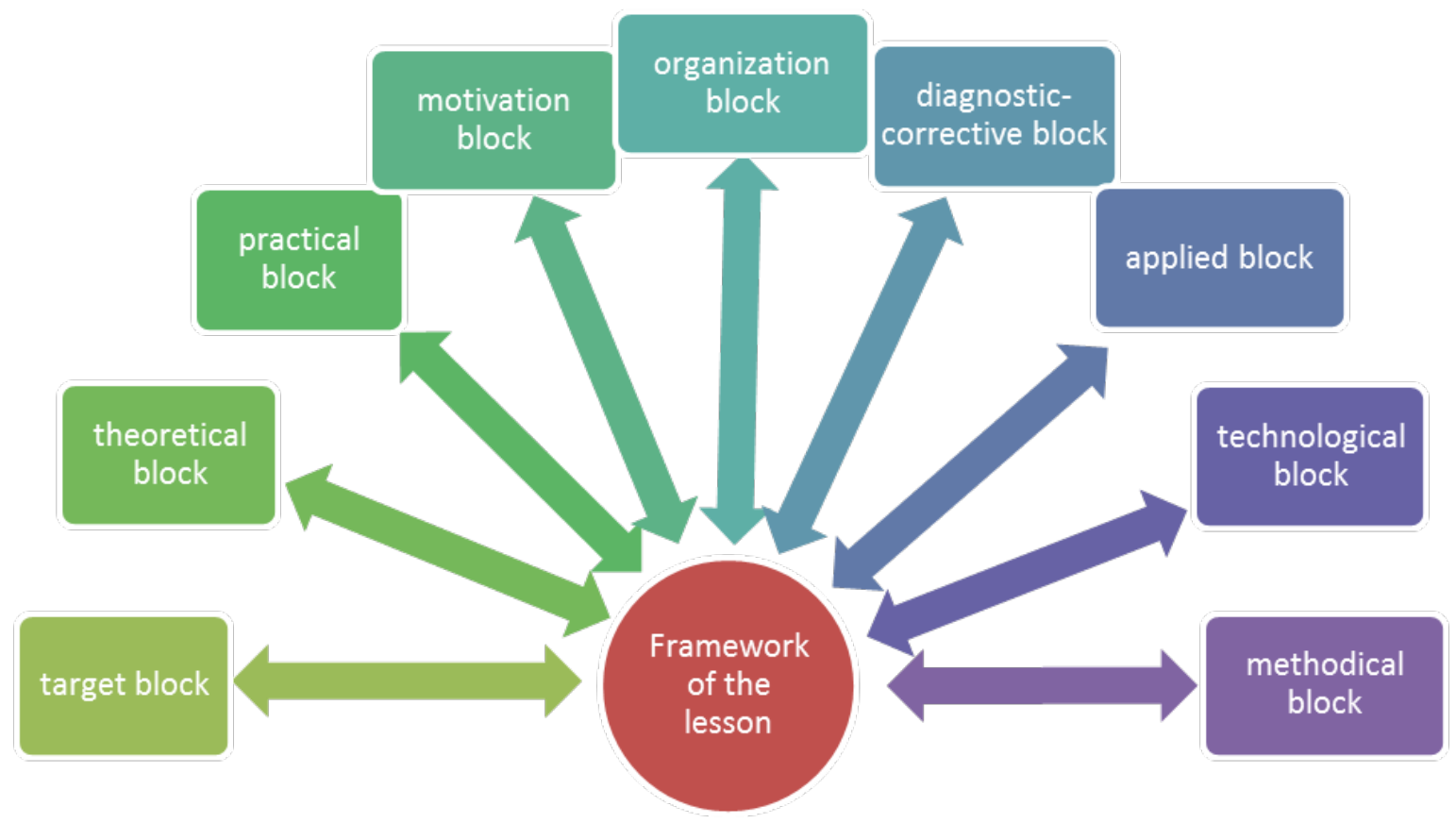

Figure 1. Model of electronic didactic project of the lesson of mathematics 
In order to determine the main advantages of the electronic didactic projects of the lessons of mathematics in the conditions of the dual education, developed by the authors, the technique of the expert assessment (Delphi method) was used. Basic stages of the realization of the method of expert assessment in the given study are: selection of the experts; determination of various factors (points of view) for the interview, conducting the interview, analysis of the interview results and processing of the results. The students of the Bachelor and Master education levels of the specialty 014 Secondary Education (Mathematics), who, at the Directors of school request (shortage of the teachers of mathematics at schools), got the permission from the University to work at schools as the teachers of mathematics in parallel with the study - 18 persons became the experts.

In the survey form, 10 factors were indicated: (1) Ready samples of the lessons of mathematics from the Internet helped me; (2) I do not see any advantages of this simulator as compared with other available constructors of the lesson; (3) simulator made me comprehend each structural component of the lesson, select consciously or not select it; (4) simulator enabled to comprehend the diversity of the possible variants of the lessons of mathematics construction; (5) simulator helped to learn how to prepare the convenient project of the lesson of mathematics; (6) simulator helped, in the process of the discussions with the colleagues, concentrated the attention on the actual problematic moments for the preparation at the efficient lesson of mathematics; (7) simulator helped stop using the ready samples of the plans of the lesson of mathematics, available in the Internet; (8) simulator enabled to obtain rapidly the necessary methodical help from the teachers; (9) simulator taught to take into account various components (blocks) in the preparation of the lessons of mathematics; (10) simulator enabled to reduce the time needed for the preparation of the lessons of mathematics in school.

\section{Results}

Methods of mathematical statistics, used in the study, are based on ranking. In the given case, each expert assigned the rank from 10 to 1 to each factor (in descending order to determine their relative significance).

The necessary condition of the reliability of the collective assessment is the sufficient coordination of the thoughts of the surveyed experts. For the determination of the group assessments coordination, the investigators used the concordance coefficient - aggregate coefficient of the rank correlation for the group of experts. Processing of the results of the expert survey took place in the following way (Table 1).

For each factor, we found the total rank, the average rank, based on which we determined the rank of the factor (Table 2, Fig. 2).

Table 1. Factor evaluation ranks

\begin{tabular}{|c|c|c|c|c|c|c|c|c|c|c|}
\hline Number of the factor & 1 & 2 & 3 & 4 & 5 & 6 & 7 & 8 & 9 \\
\hline Expert 1 & $\mathrm{X}_{11}$ & $\mathrm{X}_{12}$ & $\mathrm{X}_{13}$ & $\mathrm{X}_{14}$ & $\mathrm{X}_{15}$ & $\mathrm{X}_{16}$ & $\mathrm{X}_{17}$ & $\mathrm{X}_{18}$ & $\mathrm{X}_{19}$ & $\mathrm{X}_{110}$ \\
\hline Expert 2 & $\mathrm{X}_{21}$ & $\mathrm{X}_{22}$ & $\mathrm{X}_{23}$ & $\mathrm{X}_{24}$ & $\mathrm{X}_{25}$ & $\mathrm{X}_{26}$ & $\mathrm{X}_{27}$ & $\mathrm{X}_{28}$ & $\mathrm{X}_{29}$ & $\mathrm{X}_{210}$ \\
\hline$\cdots \cdots$ & $\cdots$ & $\cdots$ & $\cdots$ & $\cdots$ & $\cdots$ & $\ldots$ & $\cdots$ & $\cdots$ \\
\hline Expert 18 & $\mathrm{X}_{181}$ & $\mathrm{X}_{182}$ & $\mathrm{X}_{183}$ & $\mathrm{X}_{184}$ & $\mathrm{X}_{185}$ & $\mathrm{X}_{186}$ & $\mathrm{X}_{187}$ & $\mathrm{X}_{188}$ & $\mathrm{X}_{189}$ & $\mathrm{X}_{1810}$ \\
\hline
\end{tabular}

Table 2. Factor ranks

\begin{tabular}{|c|c|c|c|c|c|c|c|c|c|c|}
\hline Factors & 1 & 2 & 3 & 4 & 5 & 6 & 7 & 8 & 9 \\
\hline Average rank & 2.72 & 3.89 & 7.38 & 3.94 & 9.56 & 4.61 & 6.33 & 8.56 & 8 & 5.28 \\
\hline Sum of ranks & 49 & 70 & 133 & 71 & 170 & 83 & 114 & 154 & 144 & 95 \\
\hline Rank of the factor & 10 & 9 & 4 & 8 & 1 & 7 & 5 & 2 \\
\hline
\end{tabular}




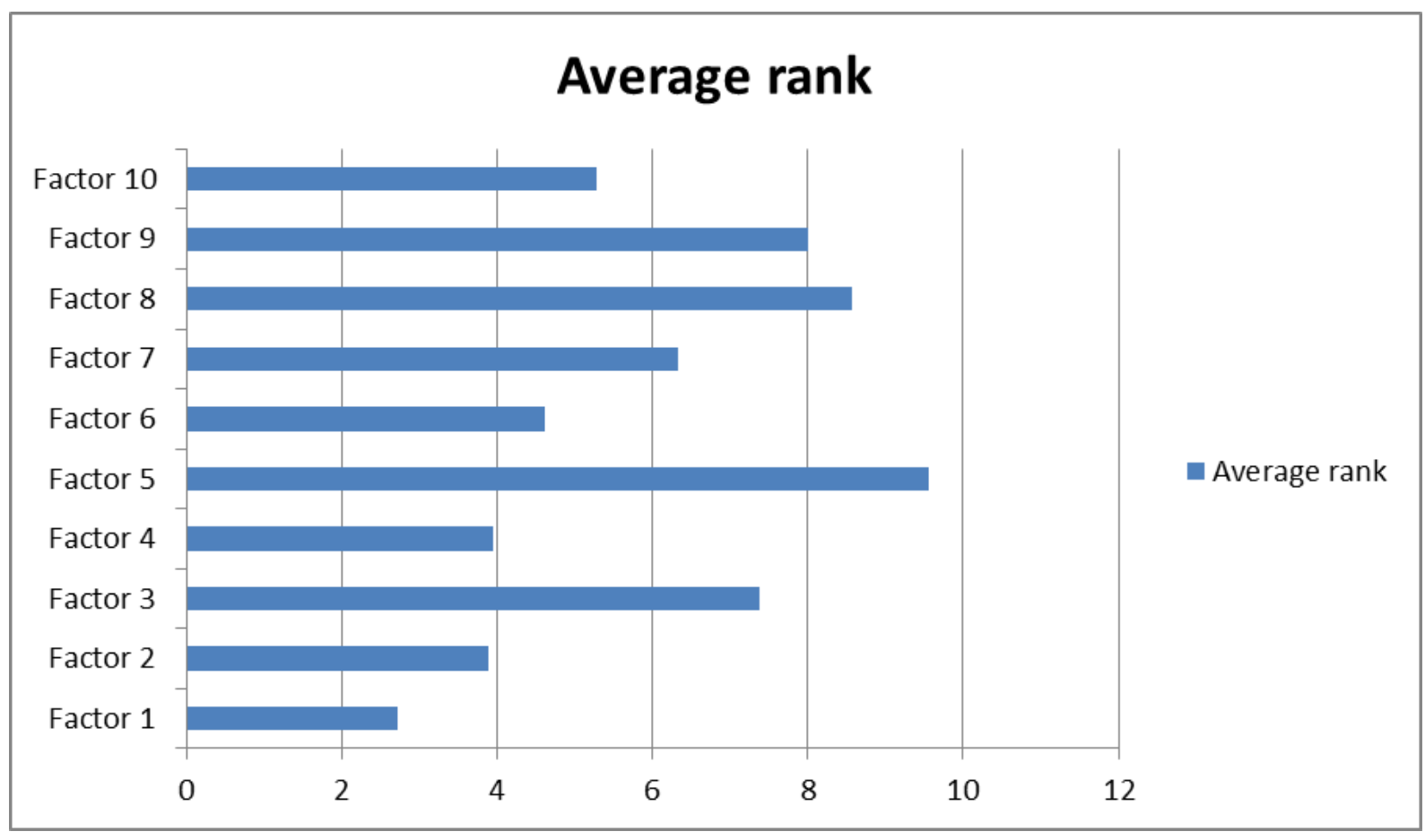

Figure 2. Rank of the factor

Thus, the most significant turned out to be:

- simulator helped to prepare a convenient project of the lesson of mathematics;

- simulator enabled to obtain rapidly the necessary methodical assistance from the teacher;

- simulator taught to take into account various components (blocks) in the process of lessons of mathematics preparation;

- simulator made comprehend each structural component of the lesson, consciously select tr not.

Assessment of the concordance of the experts' thoughts was performed by means of the concordance coefficient, calculated by the formula (1):

$$
W=\frac{12}{m^{2}\left(n^{3}-n\right)} \sum_{j=1}^{n}\left[\sum_{i=1}^{m} x_{y}-\frac{m \cdot(n+1)}{2}\right]^{2}
$$

In this case, $\mathrm{m}=18, \mathrm{n}=10$. The obtained value of $\mathrm{W}=$ 0.6045 , which, according to the scale for the coefficients of the rank correlation is in the interval $(0.6 ; 0.8)$, means good concordance of experts' opinions. For the verification of the concordance coefficient, we will find the value of the critical point by the significance level $\alpha=$ 0.05 and the number of freedom stages $\mathrm{q}=10-1=9$ will be found. By means of Pearson's table, we will find the value $\chi_{c r}^{2}(9 ; 0.05)=10$. Actual value will be calculated by the formula (2):

$$
\chi_{f}^{2}=m(n-1) \cdot W
$$

Since $\chi_{f}^{2}>\chi_{c r}^{2}$ then the conclusion can be made regarding the significance of the concordance coefficient that proves the validity of the obtained conclusions.

Thus, the training of the future mathematics teachers for lessons preparation by means of the developed electronic didactic projects of the lessons enables to form the ability to prepare the efficient project of the lesson; creates the conditions for obtaining the rapid methodical aid from the teacher; teaches to take into account various components (blocks) in the preparation of the lessons; makes comprehend each structural component of the lesson of mathematics, consciously selecting it.

\section{Discussion}

The authors suggest their own interpretation of the meaning of the concept of the notion "electronic didactic project of the lesson of mathematics". First, electronic didactic project of the lesson is referred to the electronic devices of the educational designation, which integrated various didactic facilities, methodical materials, programming products, etc. In the educational-methodological literature, electronic facilities of the educational assignation are considered as educational tools, stored on the digital or analog media, reproduced on the electronic equipment [23] and provide creative and active mustering by the future teacher of knowledge, abilities and skills, necessary in the future professional activity [24]. Four main types of electronic educational aids are distinguished: facilities for theoretical and technological training (for instance, electronic manual); aids for practical training (for instance, virtual laboratory, computer simulator); auxiliary aids (for 
instance, a computer reference book); complex aids (for instance, electronic educational course) [24].

Thus, electronic didactic project of the lesson of mathematics is referred to the electronic aids for practical training, namely, it is a special-purpose computer simulator, it is intended for the creation of the conditions for individual activity and information interaction between the teacher and the student in the process of formation of future teachers abilities to prepare for the lesson of mathematics at school.

In authors' opinion, the electronic didactic project of the lesson is not the analog to the constructor of the lesson of mathematics. Under the constructor of the lesson, the researchers mean the convenient tool that can be efficiently used by the creative teacher of mathematics, it contains the components, which are selected, accumulated or created in the process of active methodological activity during certain period of time. In scientific pedagogical literature, the constructor of the lesson is considered as the creation of the separate themes of the lessons of various types, screens (steps), new lessons, supplement to the created lesson and elimination of certain screens, tests and tasks from the lesson; import /export of the created lesson or media object in the file; formatting of the text information, paragraphs, formulas writing; formatting of the graphic information; saving of the created lesson at the exit from the constructor in the file [23].

Electronic didactic project of the lesson is developed for the educational purposes and may contain both quality materials and specially selected theoretical data, methodological developments, tasks or low-quality material. As an argument: in real conditions of the individual preparation for the lesson by the student or teacher-beginner, these materials may be taken from the Internet, in the process of preparation for certain lesson of mathematics. Thus, the filling of each electronic didactic project of the lesson is performed by the collective of the experienced teachers-instructors. In this way, we create at the department the bank of electronic didactic projects of the lessons on different subjects of school mathematics. For instance, in the process of training of future mathematics teachers, electronic didactic projects of the lessons are prepared and tested: "Geometric transformations in the plane", "Equality of the triangles", "Similarity of the triangles", "Solution of the right triangles".

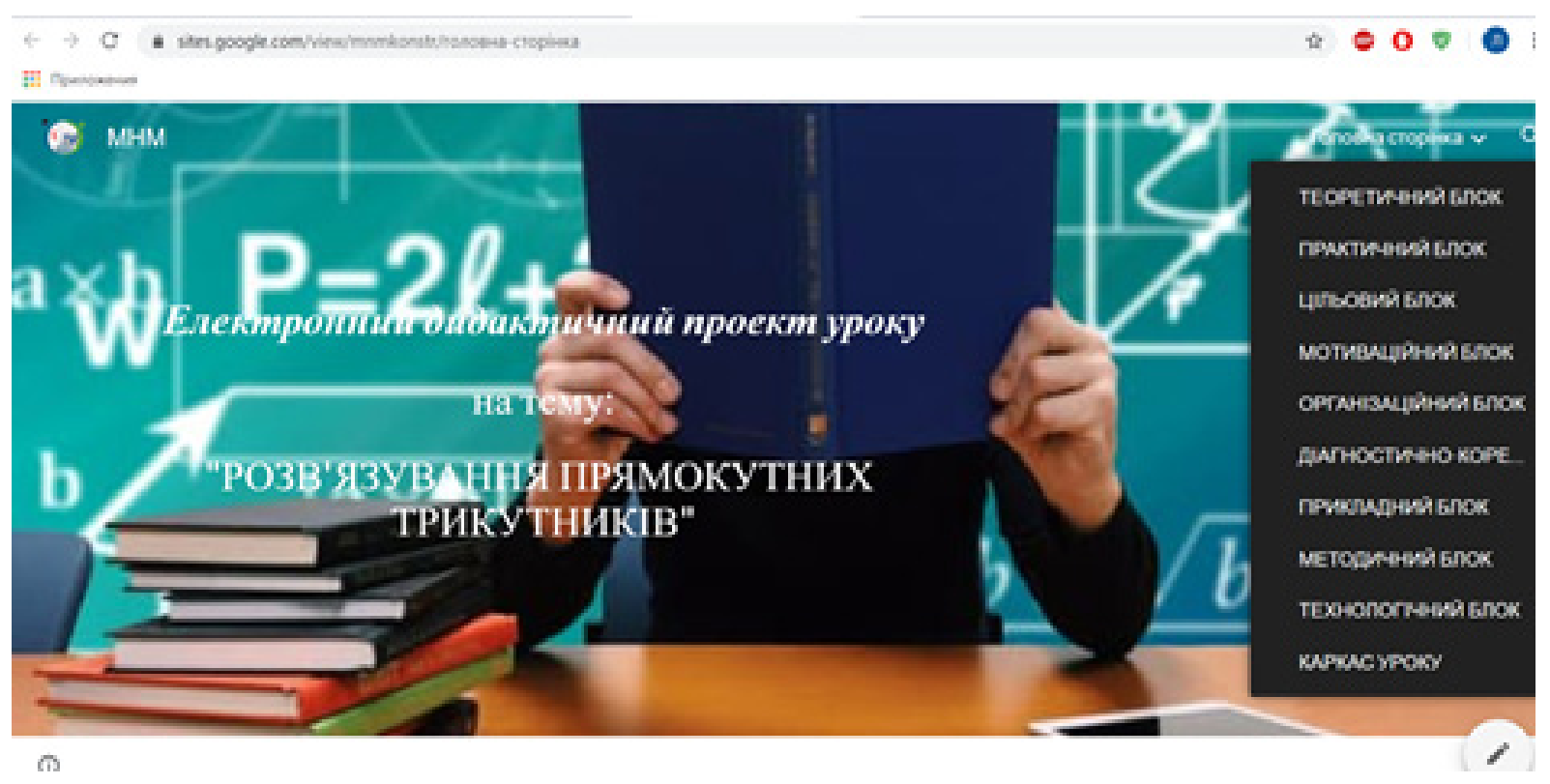

Figure 3. External view of the web-page "Electronic didactic project of the lesson" 
It should be noted that the filling of each block in the electronic didactic project of the lesson on every subject by its the volume 3-5 times exceeds the content that should really be selected for the preparation of the given lesson. That is, the student must perform the profound analysis of the available material, select the needed material, and critically comprehend its correspondence to the scientific principles and accessibility for the pupils. The simulator enables to focus students' attention on the lesson design but not on the search of the materials for the lesson. Electronic didactic project of the lesson on each theme (simulator) is stored in the form of a Google site (https://sites.google.com/view/mnmkonstr). Simulator creates the conditions for the individual execution of the assignment (preparation for the specific lesson), as all the students work with one simulator, that is why, the teacher can easily determine the already used results. The teacher -instructor knows well the content, aims and characteristic features of the simulator that is why, he is ready and able to orient in the problem, dealing with the quality of student preparation of the lesson and quickly render necessary methodological aid, organize the discussions of the problematic fragments of the lessons. We noted that the task of getting ready for the specific lesson of mathematics, preparing the plan of such lesson (prior the development of our simulators) was often reduced by the students to the search in the Internet the ready development of the lesson on the given topic or the attempts of the students to select independently the materials often led to the "digging into the routine information".

Prospects of the further research the authors see in an active filling of the bank of the electronic didactic projects of the lessons, improvement of the quality of the corresponding developments, wider expansion of the experiment, preparation of the methodical recommendations for the teachers of pedagogical universities regarding the application of the electronic didactic projects of the lessons of mathematics in the conditions of dual education of the future mathematics teachers.

One of the aims of the implementation of dual education for the training of future mathematics teachers is the following: eliminate main drawback of the conventional forms and methods of future teachers training - gap between theory and practice, traditional canons of teacher's education and modern objective needs of teachers-beginners in the condition of the reforms, taking place in Ukrainian system of education. Among the expected results of the implementation of the dual system of education for the training of future mathematics teachers, the following should be noted:

- improvement of the quality of teachers training, according to modern requirements;

- expansion and improvement of the practical component of the training program, maintaining the sufficient level of theoretical training;

upgrading of the technological background of the future mathematics teachers;

- reduction of the adaptation period of the graduates of the Pedagogical University to the professional activity in the capacity of the teachers of mathematics;

improvement of the students' motivation for the achievement of high results in studies.

\section{Conclusions}

On the given example of the methodical activity of the teacher (preparation for the lesson), the authors found out that in order to achieve the above-mentioned results of the dual form of education in training of future mathematics teachers, it is expedient to use information-communication technologies of education. Electronic device for the practical preparation of the future teachers to the lesson of mathematics at school, suggested in the paper, is developed as the simulator, intended for the formation of the ability to design lesson of mathematics, taking into account the important methodological aspects. Electronic didactic project of the lesson of mathematics gives the possibility to the teacher-student in the process of preparation for the lesson to concentrate the attention on the profound analysis of the suggested material, selection of the needed material, critical comprehension of the structure and content of the education material, design of the own activity and pupils' activity. As the studies have shown, the suggested electronic facility enables to form in the future teachers of mathematics the ability to prepare qualitative project of the lesson of mathematics; creates the conditions for the rapid methodical aid from the instructors; teaches to take into account various components in preparation for the lessons of mathematics. At the same time, in the process of testing the electronic didactic projects of the prepared lessons of mathematics, we found out the possibilities of improvement their content and indicated actual tasks for further studies regarding the possibilities of application of the developed simulators.

\section{REFERENCES}

[1] I. Savchenko. Methodological approaches and organizational features of training of skilled workers in the conditions of dual system of vocational education: experience of the EU countries and the first stages of realization in Ukraine, Mon.gov.ua., Online available from https://mon.gov.ua/storage/app/media/pto/dualna/7-savchen ko-170217.pdf.

[2] Dual education, Mon.gov.ua. Online available from 
https://mon.gov.ua/ua/osvita/profesijno-tehnichna-osvita/du alna-osvita.

[3] On approval of the Concept of training specialists in the dual form of education, Zakonodavstvo Ukrainy, 2018. Online available from https://zakon.rada.gov.ua/laws/show/ 660-2018-p.

[4] C. Jackson et al. Prospective mathematics teacher preparation: exploring the use of service learning as a field experience, Fields Mathematics Education Journal, vol. 3, no. 1,2018 . doi:10.1186/s40928-018-0010-5

[5] R. Huang, R. Zbiek. Prospective Secondary Mathematics Teacher Preparation and Technology, ICME-13 Topical Surveys, pp. 17-23, 2016. doi: 10.1007/978-3-319-38965-3 -3.

[6] K. Rogers, R. Petrulis, S. Yee, J. Deshler. Mathematics Graduate Student Instructor Observation Protocol (GSIOP): Development and Validation Study, International Journal of Research in Undergraduate Mathematics Education, 2019. doi: 10.1007/s40753-019-00106-4.

[7] M. Strutchens, R. Huang, L. Losano, D. Potari, B. Schwarz. Topic Study Group No. 48: Pre-service Mathematics Education of Secondary Teachers, Proceedings of the 13th International Congress on Mathematical Education, pp. 599-603, 2017. doi: 10.1007/978-3-319-62597-3_75

[8] K. Vlasenko, O. Chumak, I. Sitak , I. Lovianova , O. Kondratyeva. Training of Mathematical Disciplines Teachers for Higher Educational Institutions as a Contemporary Problem. Universal Journal of Educational

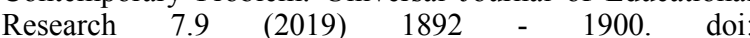
10.13189/ujer.2019.070907.

[9] V. O. Shvets, V. G. Bevz, O. V. Shkolnyi, O. I. Matiash. Chapter Ukraine: School Mathematics Education in the Last 30 Years in book Eastern European Mathematics Education in the Decades of Change. Springer, 2020. 229-274. - https://doi.org/10.1007/978-3-030-38744-0_6

[10] O. Matyash, N. Pidlisnycha. Development Of Methods Of Mental Activity Of Future Specialists In The Process Of Teaching Mathematics. Physical and Mathematical Education. 2018. Issue 4(18). 106-111. doi: 10.31110/2413-1571-2018-018-4-017

[11] L. Mykhailenko. Development of methodical competence of a math teacher as a pedagogical problem. Scientific Papers of Berdiansk State Pedagogical University Series: Pedagogical sciences. 2020. No 1, 359-369,. doi:10.31494/2412-9208-2020-1-1

[12] L. Mykhailenko, M. Kovalchuk. Formation of methodical competence in future teachers of mathematics during pedagogical practice at school. Modern informational technologies and innovative methods in professional training: methodology, theory, experience, problems. Vol.52, 349-352, 2018. Online available from https://vspu.net/sit/index.php/sit/issue/view/178

[13] N. Tarasenkova, I. Akulenko, K. Hnezdilova, I. Lovyanova. Challenges and Prospective Directions of Enhancing Teaching Mathematics Theorems in School. Universal Journal of Educational Research 7.12 (2019) 2584 - 2596. doi: 10.13189/ujer.2019.071205.

[14] S. Billett. Constituting the workplace curriculum, Journal of Curriculum Studies, vol. 38, no. 1, 31-48, 2006, doi: $10.1080 / 00220270500153781$

[15] M. Snoek. Teacher education in the Netherlands: Balancing between autonomous institutions and a steering government. European dimensions of teacher education-Similarities and differences, vol., no. 4, 53-82, 2011, Online Available from: https://www.pef.uni-lj.si/fileadmin/Datoteke/Zalozba/pdf/Z uljan_Vogrinc_Teacher_education.pdf.

[16] J. Daemen, T. Konings, T. van den Bogaart. Secondary School Mathematics Teacher Education in the Netherlands. ICME-13 Monographs, 147-175, 2020, doi: 10.1007/978-3-030-33824-4_9

[17] H. Schaap, L. Baartman, E. de Bruijn. Students' Learning Processes during School-Based Learning and Workplace Learning in Vocational Education: A Review, Vocations and Learning, vol. 5, no. 2, 99-117, 2011, doi: $10.1007 / \mathrm{s} 12186-011-9069-2$

[18] S. Hegedus et al. Uses of Technology in Upper Secondary Mathematics Education, ICME-13 Topical Surveys, 1-36, 2016, doi: 10.1007/978-3-319-42611-2_1

[19] I. Stavytska. Information and communication technologies in education, Latest Educational Technologies: Scientific and Practical Conference: Materials of Conf., 2018, Online Available from: http://confesp. fl. kpi. ua/node/1103

[20] Law of Ukraine "On Education”, Zakon.rada.gov.ua, 2017, Online Available from: https://zakon.rada.gov.ua/laws/sho w/2145-19.

[21] Law of Ukraine "On Higher Education”, Zakon.help, 2014, Online Available from: https://zakon.help/law/1556-VII.

[22] Letter of the Ministry of Education and Science №1 / 9-630 dated 05.12.2014. On steadfast adherence to the principles of guaranteeing the freedom of teacher's pedagogical activity, Osvita.UA, 2020, Online Available from https://osvita.ua/legislation/Ser_osv/44417/.

[23] On Approving the Procedure of provision of stamps and certificates of the Ministry of Education and Science of Ukraine for textbooks, learning tools and training equipment: Order of Ministry of Education and Science of Ukraine of 17.06.2008 № 537, Online available from http://zakon4.rada.gov.ua/laws/show/z0628-08.

[24] O. Balalayeva. Facet classifications of electronic teaching aids, Information technology and teaching aids, Volume 38, №6, p. 41-52, 2013, doi: 10.33407 / itlt.v38i6.926 